\title{
TUBERCULOUS LESIONS IN SLAUGHTER PIGS FROM THE VIEWPOINT OF FOOD HYGIENE
}

\author{
M. PAVLAS, VLASTA PATLOKOVÁ and E. MESÁROŠ*
}

Veterinary Research Institute, 62132 Brno

${ }^{\star}$ Regional Branch of the State Veterinary Administration of the Ministry of Agriculture and Food of the Czech Socialist Republic, 61800 Brno

Received September 21, 1984

\begin{abstract}
Pavlas M., Vlasta Patloková, E. Mesároš: Tuberculous Lesions in Slaughter Pigs from the Viewpoint of Food Hygiene. Acta vet. Brno, 54, 1985: 217-222.

Serotyping of 220 strains of mycobacteria involved in the tuberculosis of slaughter pigs in Czechoslovakia in 1974-1981 showed that the involvement of Mycobacterium avium serotype 2, 3 in tuberculous lesions during this period decreased from $90.3 \%$ to $39.1 \%$, while representation of Mycobacterium intracellulare rose from $6.5 \%$ to $50.5 \%$. Musculature specimens from $M$. avium-infected pigs with gross tuberculous lesions in the lung, liver or spleen yielded avian mycobacteria in $33 \%$ of the animals examined. No mycobacteria could be demonstrated in musculature specimens from $111 M$. intracellulare serotype 4,8 - infected pigs with primary tuberculous lesions in the lymph nodes. Isolation attempts from grossly normal mesenteric lymph nodes of slaughter pigs with negative tuberculosis findings at the slaughterhouse yielded $M$. avium and M. intracellulare in $16.7 \%$ and $4.9 \%$ of the animals, respectively.
\end{abstract}

Tuberculosis of pigs, Mycobacterium avium, Mycobacterium intracellulare, food hygiene.

In Czechoslovakia, the incidence of tuberculosis in pigs has declined since bovine tuberculosis was eradicated from cattle. Whereas in an examination of lymph node and organ specimens taken from slaughter pigs in the abattoir of Brno in 1962, $82 \%$ of a total of 51 isolated mycobacterial strains were identified as Mycobacterium avium and $9.8 \%$ as Mycobacterium bovis (Hejlíček 1966), only isolated findings of $M$. bovis from pigs have been reported here since the eradication of bovine tuberculosis from cattle in Czechoslovakia. Out of 11686 pig lymph node and organ specimens examined for tuberculosis in the Czech Socialist Republic in the 1975-1979 period, only 0.1 yielded $M$. bovis, while $M$. avium and atypical mycobacteria were isolated from $30.4 \%$ and $3.5 \%$ of the specimens, respectively (Krucky 1981). Since 1979 no isolations of $M$. bovis from pigs in the Czech Socialist Republic have been reported.

A similar trend was reported in other countries. In the Federal German Republic, for example, the findings of tuberculosis in slaughter pigs decreased from $2.5 \%$ to $0.3 \%$ during two years following the eradication of bovine tuberculosis; $81 \%$ of tuberculous lesions found during this period were caused by $M$. avium and $19 \%$ were due to Mycobacterium intracellulare (Piening et al. 1972). However, caseous and calcified foci in mesenteric lymph nodes may also be produced by microorganisms other than mycobacteria such as Sporotrichum schenekii and Nocardia, Staphylococcus, Actinobacillus and Actinomyces spp. (Vandenberge and Hoorens 1976).

Among pathogenic mycobacteria, the main causative agent responsible for tuberculous lesions in slaughter pigs in most European as well as non-European countries in M. avium (Kauker and Zettl 1964; Kleeberg and Nel 1969; Lesslie and Birn 1970; Engel 1970; Karlson and Thoen 1971; Jorgensen et al. 1972; Yachida and Schimizu 1973; Szabo et al. 1975; Thoen et al. 1975; Schulz 1976; Engel et al. 1978). The incidence of M. avium in pigs and other animal species is, to a considerable extent, linked with poultry husbandry practices. Different levels of infection in poultry in individual countries make themselves felt in differing contributions of $M$. avium to tuberculous lesions in pigs. This fact may also affect the occurrence of mycobacteria 
in the musculature of slaughter pigs in relation to the findings of gross tuberculous lesions ( $\mathrm{Sch}$ a a 1 1966; Bergman and Götze 1967; Grossklaus 1965; Pavlas and Patloková 1977).

The purpose of this investigation was to assess the present contributions of individual $\mathrm{Myco-}$ bacterium species to tuberculous lesions in slaughter pigs and to find whether the mycobacteria are present in the musculature of these animals.

\section{Materials and Methods}

A total of 220 strains of mycobacteria isolated from the lymph nodes and organs of slaughter pigs during the period 1974-1981 were serotyped. To assess the role of mycobacteria in relation to food hygiene we concentrated upon the occurrence of mycobacteria in the musculature and lymph nodes of slaughter pigs with tuberculosis-affected organs and of those with tuberculous lesions localized to mesenteric and submandibular or postpharyngeal lymph nodes. From each slaughter pig with gross lesions suggestive of tuberculosis specimens of the Musculus gracilis and praegenual lymph node were taken for bacteriological examination to confirm the specifity of gross findings and to determine the species and serotype of mycobacteria involved in the infection.

Tissue specimens, in quantities of approximately $1 \mathrm{~g}$, were homogenized in a mortar. When they could not be used for cultivation the day they were taken at the slaughterhouse, the homogenized tissue was treated with $3.5 \mathrm{ml}$ of $1 \mathrm{M} \mathrm{HCl}$ for 20 minutes and neutralized with $2 \mathrm{ml}$ of $2 \mathrm{M} \mathrm{NaOH}$. After centrifugation, sediment of each specimen wa inoculated into Sula's liquid medium and into two egg media and incubated at $37^{\circ} \mathrm{C}$. The resultant growth was read at 3 days and 2, 4, 6 and 8 weeks. The cultures obtained were examined for capacity to grow at 25,37 and $45^{\circ} \mathrm{C}$, and for morphological appearance and photochromogenicity. Strains suitable for serotyping were identified to species and their serotype was determined by agglutination (Schaefer 1967). Mycobacterial cultures that could not be classified by serotyping were examined for catalase activity (Pavlas 1972) presence of amidases (Bönicke 1960) and capacity to reduce nitrates (Virtanen 1960) and to hydrolyse Tween 80 (Weyne and Doubek 1965). To assess the pathogenicity and virulence of isolated strains, the mycobacterial suspensions were inoculated in 5-mg doses intramuscularly into pullets.

\section{Results}

Results of serotyping of 220 mycobacterial strains isolated from pigs with tuberculous lesions during the period 1974-1981 are presented in Table 1. It can be seen that during the 8 years the involvement of $M$. avium in tuberculous lesions declined by almost one-half i. e. from $90.3 \%$ to $52.8 \%$, while the representation of atypical

Table 1

Serotyping of mycobacteria isolated from pigs in 1974-1981

\begin{tabular}{|c|c|c|c|c|c|c|c|c|c|c|c|c|c|c|c|}
\hline \multirow[b]{2}{*}{ Period } & \multirow[b]{2}{*}{$\begin{array}{c}\text { No. } \\
\text { strains } \\
\text { isolated }\end{array}$} & \multirow{2}{*}{\multicolumn{2}{|c|}{$\begin{array}{l}\text { M. avium } \\
\text { Serotype } \\
\begin{array}{ll}1 & 2 \\
1\end{array}\end{array}$}} & \multirow[b]{2}{*}{ Total } & \multicolumn{11}{|c|}{ No. strains examined } \\
\hline & & & & & 4 & M. i & $\begin{array}{r}\text { Atrac } \\
8 \text {, } \\
\text { Serot }\end{array}$ & $\begin{array}{l}\text { ullul } \\
\text { ype } \\
48,9\end{array}$ & & 10 & $\begin{array}{l}\text { Total } \\
\text { No. }\end{array}$ & $\begin{array}{c}\text { M. avium } \\
\text { intracel- } \\
\text { lulare }\end{array}$ & $\begin{array}{c}\text { M. scro- } \\
\text { fula- } \\
\text { ceum }\end{array}$ & $\begin{array}{c}\text { M. } \\
\text { terrae }\end{array}$ & $\begin{array}{c}\text { No. } \\
\text { strains } \\
\text { not } \\
\text { identi- } \\
\text { fied }\end{array}$ \\
\hline $\begin{array}{r}1974 \\
-75\end{array}$ & 31 & & 27 & $\begin{array}{l}26 \\
90,3 \%\end{array}$ & & 2 & & & & & $\begin{array}{l}2 \\
6,5 \%\end{array}$ & & & & $13 \%$ \\
\hline $\begin{array}{r}1976 \\
-77\end{array}$ & 52 & .113 & 16 & $\begin{array}{l}30 \\
57,7 \%\end{array}$ & 2 & 20 & & & & & $\begin{array}{l}22 \\
42,3 \%\end{array}$ & & & & \\
\hline $\begin{array}{r}1978 \\
-79\end{array}$ & 40 & 312 & 5 & $\begin{array}{l}20 \\
50.0 \%\end{array}$ & 3 & 5 & 4 & & & 3 & $\begin{array}{l}15 \\
37.5 \%\end{array}$ & $\begin{array}{l}3 \\
7.5 \%\end{array}$ & & & $25 \%$ \\
\hline $\begin{array}{r}1980 \\
-81\end{array}$ & 97 & 529 & 4 & $\begin{array}{l}38 \\
39.1 \%\end{array}$ & 2 & 34 & 8 & 3 & 2 & & $\begin{array}{l}49 \\
50.5 \%\end{array}$ & $5.2 \%$ & $1 \%$ & $1 \%$ & $\begin{array}{l}3 \\
3.2 \%\end{array}$ \\
\hline Total & 230 & 955 & 52 & $\begin{array}{l}116 \\
52.7 \%\end{array}$ & 7 & 61 & 12 & 3 & 2 & 3 & $\begin{array}{l}88 \\
40.0 \%\end{array}$ & $\begin{array}{l}8 \\
3.6 \%\end{array}$ & $\begin{array}{l}1 \\
0.5 \%\end{array}$ & $\begin{array}{l}1 \\
0.5 \%\end{array}$ & $\begin{array}{l}6 \\
2.7 \%\end{array}$ \\
\hline
\end{tabular}


mycobacteria showed a tenfold increase. These findings prompted us to study the effect of the reduced proportion of avian mycobacteria on their incidence in the musculature of slaughter pigs. In 1982 we examined lymph nodes and organs of 132 slaughter pigs with tuberculous lesions from four large feeding operations or co-operative farms. In three localities our isolation attempts yielded atypical mycobacteria - $M$. intracellulare serotype 8 and 4,8 without any findings of $M$. avium (Table 2). On one

Table 2

Results of bacteriological examination of lymph nodes and organs from pigs with gross tuberculous lesions

\begin{tabular}{|c|c|c|c|c|c|c|c|c|c|c|c|}
\hline Locality & $\begin{array}{c}\text { No. } \\
\text { pigs } \\
\text { exami- } \\
\text { ned }\end{array}$ & $\begin{array}{l}\text { Spec } \\
\text { organ }\end{array}$ & $\begin{array}{l}\text { ens } \\
\text { No. }\end{array}$ & $\begin{array}{l}\quad \text { No. sp } \\
\text { positive on } \\
\text { culture }\end{array}$ & $\begin{array}{l}\text { ecimens } \\
\text { negative } \\
\text { on culture }\end{array}$ & $\begin{array}{c}\text { No. } \\
\text { conta- } \\
\text { minated }\end{array}$ & $\begin{array}{c}\text { Mycol } \\
\text { M. avi } \\
2\end{array}$ & $\begin{array}{l}\text { bact } \\
\text { and s } \\
\text { ium } \\
2,3\end{array}$ & $\begin{array}{c}\text { erium s } \\
\text { erotype } \\
\text { M. in } \\
\text { llulare } \\
8\end{array}$ & $\begin{array}{r}\text { pecies } \\
\text { trace- } \\
4.8\end{array}$ & $\begin{array}{c}\text { No. } \\
\text { strains } \\
\text { not } \\
\text { identi- } \\
\text { fied }\end{array}$ \\
\hline $\begin{array}{l}\text { Feeding } \\
\text { operation } \\
\text { Če. }\end{array}$ & 10 & $\begin{array}{l}\text { A } \\
\text { B } \\
\text { C, D }\end{array}$ & $\begin{array}{l}7 \\
3 \\
\end{array}$ & $\begin{array}{l}2 \\
3 \\
-\end{array}$ & $\frac{4}{-}$ & $\frac{1}{-}$ & - & Z & $\bar{z}$ & $\begin{array}{r}2 \\
2 \\
-\end{array}$ & $\overline{1}$ \\
\hline $\begin{array}{l}\text { Co-operative } \\
\text { farm N. V. }\end{array}$ & 49 & $\begin{array}{l}\text { A } \\
\text { B } \\
\text { C, D }\end{array}$ & $\begin{array}{r}39 \\
1 \\
11\end{array}$ & $\begin{array}{r}12 \\
1 \\
8\end{array}$ & $\frac{27}{3}$ & E & $\begin{array}{l}6 \\
1 \\
4\end{array}$ & $\frac{6}{4}$ & $=$ & $\overline{-}$ & E \\
\hline $\begin{array}{l}\text { Feeding } \\
\text { operation Sm. }\end{array}$ & 61 & $\begin{array}{l}\mathbf{A} \\
\mathbf{B} \\
\mathbf{C}\end{array}$ & $\begin{array}{r}29 \\
6 \\
26\end{array}$ & $\begin{array}{l}9 \\
3 \\
2\end{array}$ & $\begin{array}{r}20 \\
3 \\
24\end{array}$ & $=$ & $\bar{z}$ & $\overline{-}$ & E & $\begin{array}{l}9 \\
3 \\
2\end{array}$ & $\overline{-}$ \\
\hline $\begin{array}{l}\text { Co-operative } \\
\text { farm Vys. }\end{array}$ & 12 & $\begin{array}{l}\mathrm{A} \\
\mathrm{B} \\
\mathrm{D}\end{array}$ & $\frac{11}{1}$ & $\underline{-}$ & $\frac{6}{1}$ & E & $=$ & $\overline{-}$ & $\frac{1}{-}$ & $\frac{3}{-}$ & $\frac{1}{-}$ \\
\hline Total & 132 & & 134 & $\begin{array}{c}45 \\
100 \%\end{array}$ & 88 & 1 & $\begin{array}{l}11 \\
46.6\end{array}$ & $\begin{array}{l}10 \\
5 \%\end{array}$ & $\begin{array}{l}1 \\
48 .\end{array}$ & $\begin{array}{l}21 \\
9 \%\end{array}$ & $\begin{array}{c}2 \\
4.5 \%\end{array}$ \\
\hline
\end{tabular}

$A=$ mesenteric lymph node

$\mathrm{B}=$ submandibular postpharyngeal lymph node

$\mathrm{C}=$ pulmonary lymph node

$\mathrm{D}=$ parenchymatous organs (liver, spleen)

co-opcrative farm (N. V.), the causative agent was $M$. avium serotype 2 and 2, 3 . Tuberculous lesions in pigs from this farm were found not only in the mesenteric and submandibular lymph nodes but also in parenchymatous organs (liver, spleen and lung). In pigs coming from large feeding operation $\mathrm{Sm}$, the portal of $M$. intracellulare infection was also the upper respiratory tract. This fact was responsible for. the location of primary tuberculous lesions also in the bronchial lymph nodes in almost one-half of slaughter pigs with gross lesions in the form of caseous foci about the size of a millet to a lentil seed.

Out of 130 musculature specimens taken from a total of 130 pigs with tuberculous lesions, two yielded mycobacteria possessing properties which identified them as $M$. avium serotype 2,3 . The two pigs came from co-operative $\mathrm{N}$. V. with a history of avian tuberculosis. In another pig from the same herd with tuberculous lesions in the submandibular lymph node isolation attempts from the musculature specimen in Sula's liquid medium yielded a mycobacterial culture which could not be identified to species because of lack of growth on subculture. In the three remaining localities with findings of primary tuberculous lesions in mesenteric, submandibular and and bronchial lymph nodes produced by $M$. intracellulare serotype 8 and 4,8 , examination of the musculature yielded negative results (Table 3 ).

Musculature specimens from 61 pigs coming from large feeding operation Sm and also having caseous $M$. intracellulare-produced lesions in the bronchial, mesenteric 
Table 3

Isolations of mycobacteria from the musculature of slaughter pigs with tuberculous lesions

\begin{tabular}{|c|c|c|c|c|c|c|c|}
\hline Locality & $\begin{array}{l}\text { No. pigs } \\
\text { examined }\end{array}$ & $\begin{array}{l}\text { Organ } \\
\text { with } \\
\text { T. b. } \\
\text { lesions }\end{array}$ & $\begin{array}{l}\text { No. } \\
\text { specimens } \\
\text { examined }\end{array}$ & $\begin{array}{l}\text { No. } \\
\text { specimens } \\
\text { positive on } \\
\text { culture }\end{array}$ & $\begin{array}{c}\text { No. } \\
\text { specimens } \\
\text { negative on } \\
\text { culture }\end{array}$ & $\begin{array}{l}\text { No. con- } \\
\text { taminated }\end{array}$ & $\begin{array}{l}\text { Mycobacte- } \\
\text { rium species }\end{array}$ \\
\hline $\begin{array}{l}\text { Feeding } \\
\text { operation Če. }\end{array}$ & 10 & $\begin{array}{l}\text { A } \\
\text { B }\end{array}$ & $\begin{array}{l}7 \\
3\end{array}$ & $\begin{array}{l}0 \\
0\end{array}$ & $\begin{array}{l}7 \\
3\end{array}$ & $\begin{array}{l}0 \\
0\end{array}$ & - \\
\hline $\begin{array}{l}\text { Co-operative } \\
\text { farm N. V. }\end{array}$ & 46 & $\begin{array}{l}\text { A } \\
\text { B }, ~ D\end{array}$ & $\begin{array}{r}39 \\
1 \\
6\end{array}$ & $\begin{array}{l}1 \\
0 \\
2\end{array}$ & $\begin{array}{r}38 \\
1 \\
4\end{array}$ & $\begin{array}{l}0 \\
0 \\
0\end{array}$ & $\begin{array}{l}\text { Not indentified } \\
\text { M. avium } 2,3\end{array}$ \\
\hline $\begin{array}{l}\text { Feeding } \\
\text { operation Sm. }\end{array}$ & 61 & $\begin{array}{l}\mathbf{A} \\
\mathbf{B} \\
\mathbf{C}\end{array}$ & $\begin{array}{r}32 \\
5 \\
26\end{array}$ & $\begin{array}{l}0 \\
0 \\
0\end{array}$ & $\begin{array}{r}32 \\
5 \\
26\end{array}$ & $\begin{array}{l}0 \\
0 \\
0\end{array}$ & $\overline{-}$ \\
\hline $\begin{array}{l}\text { Co-operative } \\
\text { farm Vys. }\end{array}$ & 11 & A & 11 & 0 & 11 & 0 & - \\
\hline
\end{tabular}

$+\mathrm{A}=$ mesenteric lymph node

$\mathrm{B}=$ submandibular lymph node

$\mathrm{C}=$ bronchial lymph node

$\mathrm{D}=$ liver and spleen parenchyme

and submandibular lymph nodes, all proved negative on culture. Isolation attempts from the bronchial lymph nodes of these animals yielded positive results only in $7.7 \%$ of the specimens, which suggests rapid devitalization of $M$. intracellulare in pigs. In $M$. avium-infected pigs, on the other hand, avian mycobacteria were isolated from the affected bronchial lymph nodes in $66.7 \%$ of the specimens. Further evidence for rapid devitalization of $M$. intracellulare ist the findings that the proportion of positive isolations from all lymph node specimens was threefold lower in animals with $M$. intracellulare-produced lesions than in those with lesions due to $M$. avium.

To find to which extent it is possible to regard an outcome of meat inspection for tuberculosis as reliable evidence for decision about the approval or condemnation of pig carcasses, bacteriological examination was carried out on mesenteric lymph node and musculature specimens from 106 pig carcasses showing no gross lesions at meat inspection. These pigs came either from large feeding operation $\mathrm{Sm}$ where $M$. intracellulare has been demonstrated or from co-operative farm N. V. with a history of avian tuberculosis. Isolation attempts from their grossly normal mesenteric lymph nodes yielded $M$. intracellulare in $4,8 \%$ of 82 pigs coming from large feeding operation Sm, and $M$. avium serotype 2,3 in $16.7 \%$ of 24 pigs from cooperative farm N. V. Musculature specimens from the 106 animals all proved negative for mycobacteria on culture.

\section{Discussion}

At present, the most frequent cause of mycobacteria-produced gross lesions in slaughter pigs, particularly in large feeding operations, is $M$. intracellulare. Avian tuberculosis, on the other hand, was found on smaller farms where infection due to environmental factors (such as premises, feed and bedding contamined with faeces of domestic and free-living birds) could not be prevented and where disinfection was little effective because of continuous operation of the barns.

The decrease of avian tuberculosis among pigs in our country during the last 8 years is to be attributed not only to new feeder pig housing practices and to fewer sources of avian tuberculosis but also to other factors such as use of commercial 
feed mixtures and faithful adoption of preventive measures suggested by veterinary service. These facts, contrasting with practices of pork production in other European countries, have contributed not only to reduced incidence of tuberculosis among pigs but also to improved hygienic quality of pig carcasses with respect to the incidence of $M$. avium in their musculature.

The data reported here on the incidence of mycobacteria in the musculature of slaughter pigs with avian tuberculosis are in agreement with the results of other investigators (Krüger 1954; Grossklaus 1965; Schaal 1966; Bergmann and Götze 1967) who demonstrated $M$. avium in the musculature in $7.7 \%$ to $22.2 \%$ of specimens, depending upon the extent of tuberculous lesions. The present data on atypical mycobacteria in the musculature are of interest in that $M$. intracellulare (serotype 4,8 ) was not found in the musculature of slaughter pigs infected naturally with this $M$. intracellulare serotype.

The present findings of mycobacteria in grossly normal mesenteric lymph nodes are in keeping the observations of Weber and Schliesser (1974) who demonstrated atypical mycobacteria including $M$. avium in grossly normal mesenteric and submandibular lymph nodes in $15.2 \%$ of slaughter pigs examined.

\section{Hygienický význam tuberkulózních nálezů u jatečných prasat}

Při typizaci 220 kmenů mykobakterií podílejících se na infekci prasat tuberkulózou v období 1974-1981 bylo zjištěno, že podíl Mycobacterium avium sérotyp 2, 3 na tuberkulózních změnách u jatečných prasat klesl ve sledovaném období z 90,3 na $39,1 \%$, zatímco výskyt $M$. intracellulare se zvýšil ze 6,5 na $50,5 \%$. U prasat nakažených $M$. avium s orgánovou formou tuberkulózy lokalizovanou v plicích, játrech nebo slezině byly izolovány aviární mykobakterie ve svalovině u $33 \%$ zviŕat. Při vyšetření 111 prasat infikovaných $M$. intracellulare sérotyp $4,8 \mathrm{~s}$ nálezem tuberkulózních změn ve formě neúplného primárního komplexu v mízních uzlinách nebyly mykobakterie ve svalovině prokázány. $U$ prasat $s$ negativním nálezem tuberkulózy při veterinární prohlídce na jatkách, bylo izolováno $\mathrm{z}$ nezměněných mízních uzlin mezenteriálních $M$. avium u $16,7 \%$ a $M$. intracellulare u $4,9 \%$ jatečných prasat.

\section{Гигиеническоес значение туберкулезных результатов исследования убойных свиней}

При типизации 220 штаммов микобактерий, участвующих в инфекции свиней туберкулезом в период 1974-1981 гг. было установлено, что доля Mycobacterium avium серотип 2, 3 в туберкулезных изменениях убойных поросят в исследуемый период понизилась из 90,3 до $39,1, \%$, мсжду тем как $M$. intracellulare увеличилась из 6,5 до 50,5\%. У инфицированных $M$. avium поросят с органической формой туберкулеза легких, печени или целезенки были изолированы авиарные микобактерии в мышечной ткани у $33 \%$ животных. При обследовании 111 свиней, инфицированных $M$. intracellulare серотип 4, 8 с определением туберкулезных изменений в форме неполного первичного комплекса в лимфатических узлах микобактерии в мышечной ткани не были обнаружены. У поросят с отрицательным анализом туберкулеза при ветосмотре на бойне было изолировано из неизмененных лимфатических мезентериальных узлов $M$. avium у $16,7 \%$ и $M$. intracellulare у $4,9 \%$ убойных свиней. 


\section{References}

BERGMANN, E. - GÖTZE, V.: Untersuchungen an tuberkulösveränderten Mesenterallymphknoten des Schweines mit besonderer Berücksichtigung der Frage des Vorkommens von Mykobakterien im Fleisch. Arch. Lebensmittelhyg., 18, 1967: 104-109.

BÖNICKE, R.: Classification of mycobacteria by means of chemical test. Bull. Un. intern. Tuberc., 28, 1960: $153-156$.

ENGEL, H. W. B.: Atypical mycobacteria with special reference to the "Avium-Battey-Swine-Complex". Neth. J. vet. Sci., 3, 1970: 65-74.

ENGEL, H. W. B. - GROOTHUIS, D. G. - KÖNIG, C. D. W. - LENDFERS, L. H. H.: Pig compost as a source of Mycobacterium avium infection in swine. Vet. Med., 25, 1978: $373-382$.

GROSSKLAUS, D.: Untersuchungen der Mesenteriallymphknotentuberkulose des Schweines. Schlacht-Viehhof Ztg., 65, 1965: 363-368.

HEJLÍCEK, K.: K problematice tuberkulózy prasat. Vet. Med., Praha, 11, $1966479-484$.

JORGENSEN, J. B. - HAARBO, K. - DAM, A. - ENGBAEK, H. C. An enzootic of pulmonary tuberculosis in pigs caused by $M$. avium. Acta vet. scand., 13, $197256-86$.

KARLSON, A. G. - THOEN, C. O. Mycobacterium avium in tuberculous adenitis in swine. Am. J. Vet. Rev., 32, $19711257-1261$.

KAUKER, E. - ZETTL, K.: Beitrag zur käsigen Lymphknotenentzündung der Schweine. Berl. Münch. tierärztl. Wschr., 77, 1964: 173-192.

KLEEBERG, H. H. - NEL, E. E.: Porcine mycobacterial lymphadenitis. JI S. Afr. vet. med. Ass., 40, 1969: 233-250.

KRUCKÝ, J.: Výskyt mykobaktérií ve vyšetřovaných vzorcích v letech $1975-79$. Veterinářství, 318, 1981: $362-365$.

KRƯGER, CH.: Untersuchungen über das Vorkommen von Tuberkelbakterien im Fleisch tuberkulöser Schweine. Inaugural-Dissertation. Giessen, Justus Liebig Universität 1954. 45 p.

LESSLIE, I. W. - BIRN, K. J.: Mycobacterium avium in cattle and pigs in Great Britain. Tubercle, 51, 1970: $446-451$.

PAVLAS, M.: Katalázová aktivita $M$. avium a nonchromogenních mykobakterii intermediární skupiny. Vet. Med., Praha, 18, 1973: 677-683.

PAVLAS, M. - PATLOKOVÁ, V.: Výskyt $M$. avium a $M$. intracellulare v orgánech a svalovině jatečných prasat. Vet. Med., Praha, 22, 1977: 1-8.

PIENING, G. - ANZ, W. - MEISSNER, G.: Serotyp - Bestimmungen und ihre Bedeutung für epidemiologische Untersuchungen bei der Schweinetuberkulose in Schleswig-Holstein. Dte tierärztl. Wschr., 79, 1979: 316-319.

SCHAAL, E.: Weitere Untersuchungen über das Vorkommen von Mykobakterien im Fleisch bei der isolierten Lymphknotentuberkulose des Schweines. Schlacht-Viehhof Ztg., 66, 1966: $10-15$.

SCHAEFER, W. B.: Serologic identification of the atypical mycobacteria and its value in epidemiologic studies. Am. Rev. resp. Dis., 96, 1967: 115-118.

SCHULZ, W.: Die Mykobakteriose des Schweines. Mh. VetMed., 19, 1976: 747 -752

SZABO, J. - TUBOLY, S. - SZÉKY, A. - KEKERES, J. - UDVÁRDY, N.: Swine lymphadenitis due to Mycobacterium avium and atypical mycobacteria. Acta vet. hung., 25, 1975: $77-83$.

THOEN, C. O. - JARNAGIN, J. L. - RICHARDS, W. D.: Isolation and identification of mycobacteria from porcine tissues: a three year summary. Am. J. vet. Res., 36, 1975: 1 383-1 386.

VANDERBERGHE, J. - HOORENS, J. Actinomycotic lesions in addition to tuberculous infections in slaughtered pigs. J. comp. Path., 89, 1979: 597-600.

VIRTANEN, J.: A study of nitrate reduction by mycobacteria. Acta tuberc. scand., 48, 1960: $1-5$.

WEBER, A. - SCHLIESSER, T.: Zum Nachweis von sog. atypischen Mykobakterien in Kopf und Darmlymphknoten. Zbl. VetMed. B, 21, 1974: 799-806.

WEYNE, L. G. - DOUBEK, R. J.: Classification and identification of mycobacteria. Am. Rev. resp. Dis., 91, $1965738-745$.

YACHIDA, S. - SHIMIZU, K.: Studies on atypical mycobacteria isolated from tuberculous lesions of the mesenteric lymph nodes of slaughtered pigs. Jap. J. vet. Sci., 35, 1973: 459 - 471. 